\title{
The European Directive on Preventing and Combating Trafficking in Human Beings and the Victim-Centric Treatment of this Criminal Phenomenon
}

\author{
Carolina Villacampa Estiarte
}

\begin{abstract}
With the adoption of Directive 2011/36/EU on preventing and combating trafficking in human beings and protecting its victims, the European Union seems to have adopted a victimcentric focus to combat this phenomenon. This new form of treatment contrasts with what was traditionally upheld by the Union. This contribution will analyse both the essential elements of a victim-centric approach to human trafficking, as well as the essential contents of the new Directive.
\end{abstract}

\section{Introduction}

On 5th April, 2011, the European Parliament and the Council signed Directive $2011 / 36 /$ EU on preventing and combating trafficking in human beings and protecting its victims, replacing Council Framework Decision 2002/629/JHA ${ }^{1}$, in force since 15 April $2011^{2}$. This regulation represents the culmination of a long process of changing directions in Union policy on trafficking in human beings, which began even before the Treaty of Lisbon entered into force. The Union's new approach advocates a victim-centric treatment of the issue, which is at the epicentre of the treatment of this problem in the human rights of victims of the trafficking process. In contrast to this new angle on the approach to this subject, the traditional policy of the European Union concerning trafficking could be designated as crime-centric, since the management of this phenomenon was limited to a merely criminal matter.

With the adoption of Directive 2011/36/EU, it can no longer be sustained that the policy of the Union is limited to the mere pretence of solving the problem through the exclusive use of criminal law. The approach to this process has become more holistic, focusing itself on protecting and recognizing the rights of the victims. In taking such an approach, however, the Union has followed in the footsteps of other international legislation considered to be the bearers of this new approach to the problem based on the recognition of the rights of the victims. Fundamental in this regard has been the Council of Europe Convention on Action against Trafficking in Human Beings, also known as the Warsaw Convention. However, even from within the Union, the 2011 Directive is praised as a step beyond the international legislation referred to in a victim-centric approach to the problem of human trafficking, albeit this alleged sensitivity to protect the rights of victims is not so when it comes to ensuring their legal residence in the countries of destination.

* Reader in Criminal Law. University of Lleida (Spain)

${ }^{1}$ OJ2011 L 101/1.

${ }^{2}$ See art. 24 Directive 2011/36/EU. 
Even with its limitations, we cannot deny that the approval of Directive 2011/ $36 / \mathrm{EU}$ represents a step in the right direction in the strengthening a Union policy that is directed towards protecting victims, which is in contrast with what Union rules have lacked up to this point in time. Compliance with the requirements in this regulation must be implemented before 6th April, 2013. The following pages will analyse the contents to be incorporated into the national laws of EU countries on trafficking in human beings.

\section{Forms of Treatment for the Phenomenon in International Law: Victim-centric Versus Crime-centric Approach}

Human trafficking is a multifaceted problem, with very distinct ramifications that are highly complex to deal with and, as such, this allows for different approaches. One plan that stands out among the different forms, once the root problem is identified, focuses on the design of a strategy to eradicate it. This applies, for example, to a proposal on trafficking that is based on the treatment of this issue as related to the laws of supply and demand in the market ${ }^{3}$. From a legal point of view, the prospects for analysing this phenomenon may be limited to five: migration, work inclination, outlawing slavery, criminal justice and criminal law and, finally, human rights ${ }^{4}$.

Focusing on the latter two ways of approaching the phenomenon referred to, the most relevant ones being contemporaneous, we can observe the supranational policy instruments of today as having a dichotomous approach to the problem that distinguishes them and corresponds with a crime-centric approach, or with a victim-centric approach for this situation. Therefore, on the one hand, we find ourselves with international and regional legislation that address the trafficking of human beings essentially as a phenomenon that requires incrimination, restricted to the provision of a criminal type, or the establishment of an incriminating action in the corresponding States. In contrast with this criminal-centric, punitive or fundamentally repressive treatment of this phenomenon, in recent years a different kind of approach has arisen, which directly relates trafficking with an offence against

\footnotetext{
${ }^{3}$ See about these strategies, e.g., Abadeer, The entrapment of the poor into involuntary labor, understanding the worldwide practice of modern day slavery, The Edwin Mellen Press, Lewinston/Queenston/Lampeter, 2008, p. 50 et seq. and 99 et seq.; Kara, Sex trafficking. Inside the Business of Modern Slavery, Columbia University Press, New York, 2009, p. 200 et seq.; Bales, La nueva esclavitud en la economía global, Siglo Veintiuno de España Editores, Madrid, 2000, p. 246 et seq.; Bales/Trodd/Williamson, Modern Slavery. The secret world of 27 million people, Obeworld, Oxford, 2009, p. 145 et seq.

${ }^{4}$ See Edwards, Traffic in Human Beings: At the intersection of Criminal Justice, Human Rights, Asylum/Migration and Labor, Denver Journal of International Law and Policy, 2007-2008, p. 9 et seq.; Mattar, Incorporating the Five Basic Elements of a Model Anti-trafficking in Persons Legislation in Domestic Laws: From the United Nations Protocol to the European Convention, Tulane Journal of International and Comparative Law, 14, 2005-2006, p. 357 et seq.; Zhang, Smuggling and Trafficking in Human Beings. All roads lead to America, Praeger, Westport/Connecticut/London, p. 23 et seq. For a detailed exposition for all international instruments relating to each of these approaches see Scarpa, Trafficking in human beings. Modern slavery, Oxford University Press, New York, 2008, p. 41 et seq. In Spanish literature, Villacampa Estiarte, El delito de trata de seres humanos. Una incriminación dictada desde el Derecho Internacional, Ed. Aranzadi-Thomson Reuters, Cizur Menor, 2011, p. 145 et seq.
} 
human rights. This second type of approach, which has been called victim-centric ${ }^{5}$, is that which has been emerging more recently, given that it is what has been developed by recent international legislation devoted to this subject, among which Directive 2011/36/EU can already be included. Particularly before this Directive went into effect, it could be argued that in international and supranational instruments on trafficking in human beings, two types of competing approaches were being used, the criminal-centric or punitive approach, and the victim-centric approach or that which was oriented towards the protection of human rights.

According to a criminal-centric approach, addressing the trafficking of human beings is a matter that has to do almost exclusively with criminal law. This kind of partial focus to the problem, which addresses the flank of the crime's prosecution, but in no way prevents these behaviours or protects the victim, constitutes what is typical of the initial contemporary international instruments to combat human trafficking. As background to this, we can include different global conventions against trafficking in women that were passed throughout the 20th century ${ }^{6}$. Clearly, criminal-centric approaches also address this reality in more recently adopted instruments within the United Nations, governed by the criminalizing desire of any conduct related to freely accepted prostitution, typical of the abolitionist position on prostitution. Hence, the document that arose out of the Convention for the Suppression of the Traffic in Persons and of the Exploitation of the Prostitution of Others of 2 December 1949 can be considered the immediate antecedent of that which has long been thought to be the main international instrument for combating this type of crime, the Protocol to Prevent, Suppress and Punish Trafficking in Persons, especially women and children, supplementing the United Nations Convention against Transnational Organized Crime -also known as Palermo Protocol-. Although such an instrument is intended to combat trafficking in persons as a manifestation of organized crime and, in this sense, the primary task is criminalizing, it abandons the exclusive crime-centric heritage that precedes it, starting down the path towards victim-centrism and adopting the popular 3P's strategy (prevention, protection and prosecution). However, the contemporary supranational policy document that has addressed the problem of trafficking in human beings the most clearly from a strictly crime-centric point of view has been the Council Framework Decision of 19 July, 2002, on combating trafficking in human beings (2002/629/JHA).

The last of the prospects for addressing human trafficking and perhaps now the most important and widespread for specialized doctrine is the establishment of the relationship of this phenomenon with the violation of the victim's human rights, with the consequent assumption of a victim-centric approach. Such an approach appears to place the trafficking of human beings under the historical protection of

\footnotetext{
5 These are the adjectives applied to both of these approaches in Villacampa Estiarte (fn. 4), p. 157 et seq.

${ }^{6}$ Among them, the International Agreement for the Suppression of the White Slave Traffic of 1904, the International Convention for the Suppression of the "White Slave Traffic" of 4th May, 1910, the International Convention for the Suppression of the Traffic in Women and Children of 1921, and the International Convention for the Suppression of the Traffic in Women of the Full Age of 1933.
} 
human rights. Already in some of the instruments adopted by the United Nations, and even the League of Nations itself, as well as some of those adopted by the ILO in the interwar period, emerges the paradigm of human rights protection regarding the trafficking of human beings. Therefore, the establishment of the connection between the violation of human rights of trafficked persons and the phenomenon of trafficking is one of the most traditional under International $\mathrm{Law}^{7}$. According to this type of approach, the determining factor when addressing the treatment of the problem is not so much fighting this reality with regards to the offence or criminal phenomenon, or at least not only as such, but addressing it essentially from the need to safeguard the rights of victims, focusing more on their character of prejudicial conduct to the taxpayers who suffer in their capacity of conduct with criminal relevancy.

The assumption of this approach is, therefore, its ultimate foundation in all instruments of International Law that are already issued in which some type of relationship is established between the condition of this type of behaviour and the violation of human rights. Support for the assumption of this paradigm can already be found, among others, in the Convention on the Abolition of Slavery of 1926, and in the Supplementary Convention on the Abolition of Slavery, the Slave Trade and Institutions and Practices Similar to Slavery of 1956, but also in the conventions of the International Labour Organization relating to forced labour ${ }^{8}$.

Perhaps the most significant standard-setting agency in the adoption of this concept, at least in its origins, has been, however, the United Nations ${ }^{9}$. Although the UN has been the leading international organization in the recognition and protection of human rights, its approach has been more crime-centric than victimcentric, at least judging by the provisions contained in the Protocol to Prevent, Suppress and Punish Trafficking in Persons. This is because, irrespective of what the international instruments may be on which to base an approach to the problem that starts with the recognition of human rights and of the standard-setting institution, the paradigm that is being referred to here goes beyond the application of protective international law for human rights and is based on the recognition that the mere application of incriminating international rules has been insufficient to eradicate human trafficking ${ }^{10}$. The paradigm of human rights as the only approach with

\footnotetext{
7 Zhang (fn. 4) p. 28.

${ }^{8}$ Of this opinion, Edwards, Denver Journal of International Law and Policy, 2007-2008, p. 22 et seq.

${ }^{9}$ See Scarpa (fn. 4), p. 84 et seq. This organization is, therefore, key in regulatory support for this type of approach in relation to the protection of civil rights, being demonstrated as such in, for example, Arts. 1 and 4 of the Universal Declaration of Human Rights or Art. 8 of the International Covenant on Civil and Political Rights. In reference to the protection of rights of an economic, social and cultural nature, although the International Covenant on Economic, Social and Cultural Rights contains no provision specifically relating to slavery or practices similar to it, it does recognize rights related to working in fair conditions that can be invoked in cases of labour exploitation as well as the recognition of the right of everyone "having the opportunity to earn a living by work freely chosen or accepted," -Art. 6.1-, the right of everyone to form and join unions of their choice, social security and education, among others. Regarding the human rights of women and human trafficking, the Convention on the Elimination of All Forms of Discrimination against Women-CEDAW, 1979, prohibits trafficking in women. In relation to the rights of children, we can consider both the Declaration of the Rights of the Child adopted in 1959, and in particular the Convention on the Rights of the Child of 20 November 1989, which in Article 35 requests States Parties to act to end child trafficking and the Protocols thereto.
} 
guarantees of success in human trafficking is supported by authors who seek a comprehensive approach to the phenomenon, one that is not limited to the criminalization of behaviours and, above all, to move the centre of gravity of the struggle against this phenomenon of the criminalization of conduct to the protection of victims ${ }^{11}$. Such a comprehensive approach, and as such it should be understood as basically that of the victim-centric ideal, is that which the specialized doctrine is currently advocating, almost unanimously. The general opinion is that the legal-criminal solution is only partial, and that only the path leading to reparation for victims, and further, the attack to the structural causes of trafficking, is the one that may eventually lead to solving the problem ${ }^{12}$. In short, an approach to human trafficking from the perspective of human rights demands, in addition to requiring the identification of essential rules that recognize human rights in relation to trafficking to be expressed, that the field of human rights is also a field of action, which must involve pressure on States to address the human rights implications of this phenomenon, recognizing victims as such and establishing mechanisms that make its repair possible. Beyond this, an approach to the phenomenon from the flanks of human rights should not be limited to the process itself, but must also shoulder the causes and consequences of that process $^{13}$.

\footnotetext{
${ }^{10}$ In conclusion, as Krieg, Trafficking in human beings: the EU Approach between Border Control, Law Enforcement and Human Rights, European Law Journal, vol. 15, $\mathrm{n}^{\circ}$ 6, p. 785, exposes the consideration of human trafficking as an issue related to the protection of human rights stresses the harm to the person, as opposed to the previous approach, basically protecting the interests of the State. Among the weaknesses of a crime-centric approach, Amiel, Integrating a human rights perspective into the European approach to combating the trafficking of women for sexual exploitation, Buffalo Human Rights Law Review, 12, 2006, p. 27 et seq., includes the domain of interests of the accused against those of the victims, with the consequent lack of protection and assistance measures for victims, focusing only on the push factors of trafficking, not on the pull ones.

${ }^{11}$ Widely on this approach see Obokata, Trafficking in human beings from a Human Rights Perspective: Towards a Holistic Approach, Martinus Nijhoff Publishers, Leiden/Boston, 2006, p. 32 et seq., p. 121 et seq. and p. 149 et seq. Previously from the same author, Obokata, Trafficking of Human Beings as a crime against humanity: some implications for the international legal system, International and Comparative Law Quarterly, 45, 2005, p. 445 et seq.; Obokata, Smuggling of Human Beings from a Human Rights Perspective: Obligations of Non-State and State Actors under International Human Rights Law, International Journal of Refugee Law, 17, 2005, p. 394 et seq.

${ }^{12}$ See, e.g,, Zhang (fn. 4), pp. 145 et seq.; Askola, Legal responses in Trafficking in Women for Sexual Exploitation in the European Union, Hart Publishing, Oxford-Portland Oregon, 2007, p. 133 et seq.; Segrave/Milivojevic/Pickering, Sex Trafficking. International context and response, WP William Publishing, Cullompton/Devon, 2009, p. 193 et seq.; Scarpa (fn. 4) p. 81 et seq. and 206 et seq.; Cole, Reconceptualising female trafficking: the inhuman trade in women, Cardozo Journal of Law \& Gender 12, 2005-2006, p. 802 et. seq.; Mattar, Tulane Journal of International and Comparative Law, 14, 2005-2006, p. 379 et seq.; Edwards, Denver Journal of International Law and Policy, 20072008, p. 22 et seq.; Amiel, Buffalo Human Rights Law Review, 12, 2006, p. 35 et seq.; Lenzerini, International legal instruments on human trafficking and victim-oriented approach: Which gaps are to be filled?, Intercultural Human Rights Law Review, 205, 2009, p. 226 et seq.; Waisman, Human Trafficking: State Obligations to Protect Victims Rights, the current Framework and a New Due Diligence Standard, Hastings International \& Comparative Law Review, 33, 2010, p. 385 et seq.; Gekht, Shared but Differentiated Responsibility: Integration of International Obligations in Fight Against Trafficking in Human Beings, Denver Journal of International Law \& Policy, 37, 20082009, p. 47 et seq.; Piotrowitz, The legal nature of Trafficking in Human Beings, Intercultural Human Rights Law Review, 4, 2009, p. 176 et seq.; Gallagher, Using international human rights law to better protect victims of human trafficking: the prohibitions of slavery, servitude forced labor and debt Bondage, in Sadat/Sacarf, The Theory and Practice of International Criminal Law: Essays in Honour of M. CherifBassiouni, MartinusNijhoff, Leiden, 2008, p. 397 et seq.; Bakarici, Human trafficking and forced labour: a criticism of the International Labour Organisation, Journal of Financial Crime, 2009, 16 (2), p. 160 et seq.; Piotrowitz, The UNHCR's Guidelines on Human Trafficking, International Journal of Refugee Law, 2008, 20 (2), p. 242 et seq.; Krieg, European Law Journal, vol. 15, n 6 , p. 783 et seq.
} 
Based on the above considerations, international instruments have been constructed in which the adoption of this approach is much clearer than it once was with the Palermo Protocol in its day. In this sense, perhaps the most advanced document that exists today regarding the assumption of the victim-centric paradigm is the Council of Europe Convention on Action against Trafficking in Human Beings of 2005, also known as the Warsaw Convention. The adoption of this instrument, despite the reluctance of some countries to ratify it and causing a delay in its entry into force ${ }^{14}$, and even despite the difficulties arising from the European Union itself with regard to its approval ${ }^{15}$, can be considered the consecration of the victim-oriented approach and, above all, the confirmation that the protection of its rights, that is, the assumption of the victim-centric paradigm, is not incompatible with the pursuit; in short, with achieving a criminal-centric approach.

\section{What is the Victim-centric Approach to Trafficking in Human Beings?}

To expound on the approach to trafficking from the perspective of human rights, we must clarify that this angle not only involves applying these structures and institutions of International Law, but rather from the assumption of a proposed solution of the problem, which essentially meets the needs of protection and assistance to victims, overcoming the narrowness of the court's limited crime-centric approach. This proposal cannot, therefore, rely solely on the pursuit, but should primarily be focused on the prevention and protection of victims, without abandoning considerations with regards to the need for interstate, interagency and interorganizational coordination.

Each one of these aspects, which can be considered components of a policy against trafficking in human beings articulated from the perspective of human rights, are listed in the report that the first Experts Group on Trafficking in Human Beings of the European Union issued in $2004^{16}$, largely ratified by the opinion expressed in No. 7/2010 of the second Experts Group ${ }^{17}$, which has recently been renewed, proceeding to the appointment of the third group after the Commission Decision of 10 August 2011. Reference can be made to that document, and specifically the

\footnotetext{
13 Obokata (fn. 11), p. 35 et seq.

${ }^{14}$ It was signed on May 16, 2005 but did not come into force until February 1, 2008. It has been signed by fortythree States, but only thirty-four have ratified it.

${ }^{15}$ Not only has the EU not yet ratified this instrument, despite having participated in its design, but both Parliament and the Commission of the Union also exercised their right of veto for some of the reform proposals made by the Assembly Council to the text proposed by the Ad Hoc Committee which prepared the draft, causing some of them not to be included in the final version of the document.

${ }^{16}$ It was issued in Brussels on December 22, 2004. See Experts Group on Trafficking in Human Beings, Report of the Experts Group on Trafficking in Human Beings, 2004, pdf. file available at http://ec.europa.eu/anti-trafficking/ (1402-2012).

${ }^{17}$ Vid. Group of Experts on Trafficking in Human Beings of the European Commission, Opinion No 7/2010. Proposal for a European Strategy and Priority Actions on combating and preventing trafficking in human beings (THB) and protecting the rights of trafficked and exploited persons, pdf. file available at http://ec.europa.eu/anti-trafficking/ (14-02-2012).
} 
recommendations being carried out by Member States, in order to delineate the aforementioned overview of this type of approach ${ }^{18}$.

The first aspect to be addressed by a programme to combat trafficking that intends to be victim-centric is the prevention of this phenomenon. In order to achieve this, it must insist on the root causes of trafficking, primarily by means of the States modifying the adoption of current economic policies, not compelling people to resort to irregular migratory movements and in conditions of vulnerability, implementing the provisions of international conventions on human rights of migrants, along with the implementation of gender-oriented programmes also based on these standards. In addition, the States must increase opportunities for legal migration and migration that is not produced under exploitative conditions. The cooperation of developed States with the countries of origin is also important. Knowing the causes of trafficking and taking action against them will necessarily mean being knowledgeable about this phenomenon, which requires research and the evaluation of implemented policies. Another crucial aspect in prevention is the increase in community and public awareness about this reality by means of information campaigns. Specific training of those working in this field is also needed to prevent such conduct. Administrative control, primarily of the borders, but also in areas annexed to these borders or even internal, may also constitute another important aspect with regards to prevention ${ }^{19}$, provided this is carried out with due regard to human rights and the fundamental rights of the person, including the freedom of movement. Finally, we must not forget that the specialties of children must be addressed in this field as well, which requires the adoption of specific measures to address and prevent violence, abuse and the exploitation of children ${ }^{20}$.

Regarding the second of the major concerns that make up this type of comprehensive approach, that of protecting and assisting victims of trafficking in human beings $^{21}$, it must be ensured that victims have adequate access to forms of relief, including assistance, protection and compensation, regardless of their ability or willingness to testify in hypothetical criminal proceedings. The first premise so that the victim can be afforded the right to enjoy these protection mechanisms is their identification as such, a fact that starts with the training of the system's actors in this field that can deal with actual or potential victims. All victims of trafficking in human beings must be guaranteed a period of reflection that should not be less than three months, in order that the person can recover and be able to make an informed decision about their options. After the identification, a temporary residence permit for the victim should be guaranteed, either by the will of the person to work with the administration of justice, but for other reasons, such as initiating a social programme aimed at social inclusion or training ${ }^{22}$. Together with the temporary

\footnotetext{
${ }^{18}$ See Experts Group on Trafficking in Human Beings (fn 16), p. 16 et seq. For a detailed account of what should be a state policy to address the problem from this perspective, see also Obokata (fn 11), p. 149 et seq.

${ }^{19}$ With control measures of private employment agencies or economic sectors of possible employment of trafficked persons, such as construction, the sex industry or agriculture.

${ }^{20}$ About prevention measures see Experts Group on Trafficking in Human Beings (fn 16), p. 24 et seq.

${ }^{21}$ Experts Group on Trafficking in Human Beings (fn. 16), p. 33 et seq.
} 
residence permit, it is proposed that a definitive or long-term residence permit can be adopted in situations such as the person successfully completing a social programme and finding work, for humanitarian reasons, and even the granting of asylum under the right of refugees. Such protective measures, which allow remaining in the State of destination, should apply to family members of those trafficked, especially children, if it is feared that their return to the country of origin may be dangerous for them.

With regards to assisting victims, assistance must be guaranteed in facilitating safe and appropriate housing, psychological counselling, healthcare, free legal assistance, education, career counselling and employment opportunities. Victims of trafficking in human beings in criminal proceedings should be protected regardless of their level of participation in the proceeding. Integrated in the decalogue of rights of victims in criminal proceedings is the right to be respected, the right to be informed and advised understandably, and the right to privacy and protection.

Finally, with reference to the third of the flanks that should compose a fully conceptualized strategy to combat trafficking in human beings, we need only refer to measures to be incorporated regarding the pursuit and prosecution of these crimes $^{23}$. These obviously include the criminalization of such conduct and the imposition of sanctions proportionate to the seriousness of the unjust action. However, this is not enough, since the trafficking of human beings is a crime whose commission often involves organized crime due to the high profits involved. There must be compulsory precautionary measures in relation to such organizations, as well as imposed economic sanctions to confiscate what has been earned by means of the offence. At the same time, this action against what is earned from such an offence should also be achieved through the regulation of the crime of money laundering which includes in its typical profile the profits from the commission of this crime. However, the aforementioned provisions of substantive character added to the procedure that can be arbitrated, such as the expansion of jurisdiction rules or prosecutability provisions for these crimes, will not be sufficient if not accompanied by strategies for the effective implementation of the law. These strategies should be developed by means of the appropriate training of personnel to enforce these provisions, from judges to police officers, which also must be specific for certain types of victims, including children. That the specific training of agents and other operators in this area is perhaps the most effective tool both in detecting cases of trafficking as well as managing them properly has already been shown in an empirical study carried out in the United States ${ }^{24}$. Along with this, proactive investigative techniques should be developed, in addition to developing information

\footnotetext{
${ }^{22}$ Experts Group on Trafficking in Human Beings (fn 16), p. 34, proposes to have a duration of six months and be renewable.

${ }^{23}$ Experts Group on Trafficking in Human Beings, (fn 16), p. 40 et seq.

${ }^{24}$ Farrell/McDevitt/Fahy, Understanding and improving law responses enforcement to Human Trafficking, Final Report, June 2008, Northeastern University/Institute of Race and Justice, pdf. file available at www.ncjrs.gov/ pdffiles1/nij/grants/222752.pdf (04-02-2012), pp. 19-52, where the results of an empirical study conducted with 3,000 national police agencies in the USA are presented.
} 
exchange mechanisms between the different organizations that are active in the fight against this phenomenon.

\section{Background to the Adoption of Directive 2011/36/EU on the Traf- ficking of Human Beings in the European Union}

\section{The first European phase: addressing the issue crime-centrically}

As regards the European Union, its concern about the fight against the trafficking of human beings began long ago. Even before the Amsterdam Treaty came into force and the development of the area of freedom, security and justice, the Council Joint Action 96/700/JHA of 29 November 1996, by which a programme is established to encourage and exchange the persons responsible for combating trafficking in human beings and the sexual exploitation of children, and especially Council Joint Action 97/154/JHA of 24 February 1997 on combating trafficking in human beings and the sexual exploitation of children, took steps towards the harmonization of European criminal law on this subject. At a political level the fight against this type of crime has been a priority that is reflected in the Tampere Programme (1999-2004), in The Hague (2004-2009) and finally in the current Stockholm Programme (2010-2014). That interest has also crystallized in the provision of a range of programmes that enable funding for research on this subject, such as the programme Stop, and especially Daphne, as well as the programme Prevention of and Fight Against Crime, in force 2007-2013.

The regulation instruments and policy actions referred to so far are intended to make up a sample concerning what has been felt in the European Union even before the last decade due to the phenomenon we are dealing with and the subsequent crystallization of policy instruments that have been extensively analysed in previous works ${ }^{25}$. In the policy instrument par excellence that the Union gave to combat trafficking in human beings - the Council Framework Decision of 19 July 2002 on combating trafficking in human beings (2002/629/JHA) - the strictly punitive approach to the phenomenon is obvious.

In the European Union, as well as in the scope of the United Nations, concern arose from the phenomenon of trafficking for the sexual exploitation of women and

\footnotetext{
${ }^{25}$ In relation to the EU regulation of trafficking until mid-2000 there is abundant Anglo-Saxon and Spanish literature. See, e. g., Rijken Rijken, Trafficking in persons. Prosecution from a European perspective, T. M. C. Asser Press, The Hague, 2003, p. 90 et seq.; Askola (fn 12), p. 99 et seq.; Scarpa (fn. 4), p. 171 et seq.; De Léon Villalba, Tráfico de personas e inmigración ilegal, Ed. Tirant lo Blanch, Valencia, 2003, p. 113 et seq.; Villacampa Estiarte, "Normativa europea y regulación del tráfico de personas en el Código penal español", in Rodríguez Mesa/Ruíz Rodríguez (coords.), Inmigración y sistema penal. Retos y desafíos para el Siglo XXI, Ed. Tirant lo Blanch, Valencia, 2006, p. 69 et seq.; Gugat Mauri, in García Arán (coord.), Trata de personas y explotación sexual, Ed. Comares, Granada, 2006, p. 56 et seq.; Guardiola Lago, El tráfico de personas en el Derecho penal español, 2007, Ed. AranzadiThomson Reuters, Cizur Menor, 2007, p. 58 et seq.; Pérez Alonso, "Regulación internacional y europea sobre el tráfico ilegal de personas", in Zugadía Espinar (dir.)/Pérez Alonso (coord.), El derecho penal ante el fenómeno de la inmigración, Ed. Tirant lo Blanch, Valencia, 2007, p. 54 et seq.; Pérez Alonso, Tráfico de personas e inmigración clandestina (un estudio sociológico, internacional y jurídico-penal), Ed. Tirant lo Blanch, Valencia, 2008, p. 131 et seq.
} 
children, as can be seen from the first regulatory instruments issued for this purpose. Along with this parallelism, Council Framework Decision of 19 July 2002 was also adopted in response to regulatory developments that had been operating within the United Nations, as is recognized in the very preamble of the European instrument, which sets out that this European Union action is complementary to the important work basically being developed by the United Nations. Despite these procedural parallels and temporary coincidences in the adoption of policy instruments between the European Union and the United Nations, what has differentiated the two processes is that while the United Nations has adopted a victim-centric focus limited to the phenomenon, within the European Union the focus has been primarily crime-centric, practically confining the action to be taken to the mere incrimination of criminal behaviour.

Probably the causes which led the Union to the narrowness of objectives in addressing trafficking in human beings before the process that led to the adoption of Directive 2011/36/EU must be sought out in the traditional relationship established between human trafficking and illegal migration, to which a second type of connection is added that is always established by the Union when the task has consisted of addressing the problem of trafficking, its relationship to organized crime. Both types of connections were used to delineate a scenario in which the trafficking of human beings is conceived simply as a form of organized crime that must be fought against through the use of criminal law. It had not considered that what constitutes a deeply victimizing crime also requires the establishment of minimum EU standards in areas such as protective measures to be taken in relation to the victims, both inside and outside the criminal procedure, the establishment of a decalogue for these rights, the design of mechanisms that allows them to access information about the existence of such rights, and the type of assistance to be provided and how it must be ensured, among other issues.

True to this vision, essentially repressive when it comes to finding solutions to the phenomenon, the Framework Decision of 19 July 2002 was limited, once a concept of human trafficking was established in Art.1, practically coinciding with the Protocol to Prevent, Suppress and Punish Trafficking in Persons, to determine the obligations of States regarding the criminalization of such conduct. The penalty framework was established for individuals and legal persons, and a large degree on the articles was dedicated to its determination, reserving a laconic article to protect and assist victims of this crime.

Not unlike the concept of the trafficking of human beings confined to a matter relating to the criminal justice system has been the approach that the EU has shown in further legal instruments relating to this subject still in force, at least those issued in the middle of the first decade of the 21st century. Thus, in Council Directive 2004/81/EC of 29 April 2004 on the residence permit issued to third-country nationals who are victims of trafficking in human beings or who have been the subject of an action to facilitate illegal immigration, who cooperate with the competent authorities, provides the possibility of facilitating a residence permit of 
limited duration to third-country nationals who are victims of the trafficking of human beings. This regulation stipulates a period of reflection without a fixed term in order to decide whether they want to collaborate with the administration of justice, but that is articulated as a mere instrument to these effects alone. In addition, the residence permit, of at least six months, is granted on the condition that the person has shown clear intention to cooperate and its maintenance always depends on the third-country national cooperating with the competent authorities. The trafficking victim is entitled to the permit while collaborating; from the moment the victim ceases collaborating or their collaboration is not needed because criminal proceedings have concluded, their future is left up to chance.

\section{A change of direction towards a victim-centric approach in the EU: towards the Directive 2011/36/EU}

With all the internal contradictions that are observed within the Union in addressing this issue, the EU policy, even stubborn in defending a fortress Europe, has recently changed its course. As such, the work of the Experts Group on Trafficking in Human Beings is of great significance in relation to its final report in December 2004, and the statements contained in the Brussels Declaration of 2002 regarding the need to address a victim-centric vision on the trafficking of human beings. The creation of the Experts Group on Trafficking in Human Beings was just one of the derivatives of the Brussels Declaration. Following its recommendations, the Commission ordered the creation of that group by a Decision adopted in $2003^{26}$. It was, as expressed in that Decision, a group composed of twenty members to be selected according to their competence and experience in the field of human trafficking among the administrations of EU Member States as well as among the members of intergovernmental and international organizations and NGOs. This first Experts Group was active in 2003-2004 and clearly influenced the change in orientation of Union policy on the trafficking in human beings through its report of December, 2004.

This paper addresses two overall recommendations that the Experts Group made to the Commission. On the one hand, there is a need to integrate the perspective of human rights within the legal framework for combating human trafficking with the first concern standing out as combating the exploitation of human beings in situations of forced labour or under conditions similar to slavery, whether we are dealing with a victim of trafficking, a trafficked migrant, an illegal immigrant or a legal resident. On the other hand, the second of the suggestions is the need for a multidisciplinary and integrated approach to this issue, addressing strategies on the adoption of appropriate remedies for victims of trafficking and social inclusion.

This new approach of the Union to the problem of human trafficking deducted from the report of the Experts Group had already translated into further action, but prior to the adoption of Directive 2011/36/EU. Thus, the Hague Action Pro-

${ }^{26}$ Commission Decision 2003/209/EC, of 25th March, 2003. 
gramme of 2004 recommended to both the Commission and the Council the adoption of an action plan against the trafficking of human beings in order to develop a common standard in relation to best practices and mechanisms for combating this situation, which was adopted by the Council in $2005^{27}$.

The approval of that plan involved the confirmation of the assumption by the European Union of a change of direction from the crime-centric approach to a victim-centric approach regarding the trafficking of human beings. However, it was not until the proposal of a Council Framework Decision on preventing and combating trafficking in human beings and the protection of victims of 2009 when this shift began to crystallize legally. In fact, in the working document adopted by the Commission on the evaluation and monitoring of the EU Plan on best practices, standards and procedures for combating trafficking in human beings and preventing it, which was adopted by the Commission to commemorate the second day against trafficking in human beings ${ }^{28}$, it found again that Member States were not taking the side of protecting and assisting victims. The data reflected in that document led the Commission to recognize the necessity of a review of the Framework Decision 2002/629/JAI.

From that moment, what had been a change of political course really starts to become law, thus beginning the reform process of that Decision, which finally led to the adoption of Directive 2011/36/EU. However, the adoption of this rule must be seen as a prime example to consider along with other instruments adopted by the EU recently that abound in the idea of a human rights approach to human trafficking $^{29}$. This applies, for example, in the field of migration legislation, with Directive 2009/52/EC of the European Parliament and the Council of 18th June, 2009, providing for a minimum standard on sanctions and measures against employers of illegally staying third-country nationals ${ }^{30}$ and to a lesser extent in the field of labour law, with Directive 2009/50/EC of the Council of 25th May, 2009, on the conditions of entry and residence of third-country nationals for purposes of highly qualified employment ${ }^{31}$.

As immediate background to Directive 2011/36/EU, we must refer to the proposal for a Council Framework Decision on preventing and combating trafficking in human beings and the protection of victims of 2009. Already in the working document of the Commission on the evaluation and monitoring of the implementation of the EU Plan on best practices, standards and procedures for combating

\footnotetext{
${ }^{27} \mathrm{EU}$ plan on best practices, standards and procedures for combating and preventing trafficking in human beings (2005/C 311/01).OJ 2005 C 311/1.

${ }^{28}$ See Commission Working Document, Brussels 17. 10. 2008, COM (2008) 657 final.

${ }^{29}$ About areas where the Union has ruled in recent years affecting a victim-centric approach to human trafficking, see Rijken/de Volder, "The European Union's Struggle to realize a human rights-based approach to trafficking in human beings. A call on the EU to Take THB-Sensitive Action in Relevant Areas of Law", Connecticut Journal of International Law, 25, 2009, p. 49 et seq.

${ }^{30}$ OJ 2009 L 168/24.Regarding the effects of this Directive in the fight against trafficking in human beings, see Rijken/de Volder, Connecticut Journal of International Law, 25, 2009, p. 67 et seq.

${ }^{31}$ OJ 2009 L 155/17; Rijken/de Volder, Connecticut Journal of International Law, 25, 2009, p. 67, consider that this Directive will be less effective than the previously mentioned in the fight against human trafficking.
} 
trafficking in human beings and preventing it, the need for amending Framework Decision 2002/629/JHA was suggested. Following this recommendation is how the Council Framework Decision proposal on preventing and combating trafficking in human beings and the protection of victims, thus repealing Framework Decision 2002/629/JHA of 25 March 2009, was adopted ${ }^{32}$. Specifically, the work programme of the Commission for $2009^{33}$ also provided the necessary modification of FD 2002/629/JHA, together with the proposed amendment of Framework Decision of 22nd December, 2003, on combating the sexual exploitation of children and child pornography (2004/68/JHA) and member measures for a package of actions against organized crime. Among the key reasons for reaching that decision, the Commission includes that the adoption and entry into force of the Warsaw Convention has led to the establishment of a higher standard in the fight against this type of crime and that as such, the European Union does not comply with the mere existence of the Framework Decision of $2002^{34}$. Based on studies conducted within the European Union both on the implementation of Framework Decision 2002 as well as the EU Plan, the Commission concludes that there are four major areas in which the EU response is insufficient. It considers that this situation should be remedied by modifying the existing rules. The areas where improvement is required are related to flaws in the prosecution of criminals, inadequate protection and assistance to victims, insufficient measures to prevent trafficking and finally the lack of knowledge concerning this phenomenon ${ }^{35}$.

Starting, then, from the necessity to adapt existing rules in the EU to implement the three objective policy that is proposed and basically coinciding with the $3 \mathrm{P}$ policy of the Palermo Protocol ${ }^{36}$, various policy options to achieve this have been proposed. Specifically, the Commission document refers to four possibilities ${ }^{37}$, from less to more interventionist, listed below. The first would be that no more measures are applied by the EU, even though this would not prevent Member States from continuing with the ratification and signing of the Warsaw Convention. The second was that the Union merely adopts non-legislative measures to combat this reality. The third was the adoption of new legislation on this subject, not merely limited to the modification of existing legislation, as initially proposed, but approved as a new Framework Decision. Finally, the fourth of the options, the most interventionist

\footnotetext{
${ }^{32}$ COM (2009) 136 final.

${ }^{33}$ COM (2008) 712.

${ }^{34}$ See Commission of the European Communities, Commission Staff Working document accompanying document to the Proposal for a Council Framework decision on preventing and combating trafficking in human beings, and protecting victims, repealing Framework Decision 2002/629/JAI, SEC (2009) 358, pp. 4 and 5.

${ }^{35}$ Commission of the European Communities (fn 34), pp. 13-14.

${ }^{36}$ See Commission of the European Communities, (fn 34) pp. 18-19, where four specific objectives are identified: prosecuting crime, protecting the rights of victims and preventing trafficking in human beings, and to establish an effective monitoring system. The pursuit of these four objectives has been consolidated over time. The achievement of these four objectives and the measures taken to get them are referred in the following document of the Belgian presidency of the EU Council: Council of the European Union, Presidency Conclusions from the Conference "Towards a multidisciplinary approach to prevention of trafficking in human beings, prosecution of traffickers and protection of victims" (Brussels, 18-19 October 2010), pdf. file available at http://ec.europe.eu/anti-trafficking (14-02-2012), p. 10 et seq.

${ }^{37}$ Commission of the European Communities (fn 34), pp. 20-49.
} 
and that which was adopted in the end, contemplates, in addition to the adoption of a new Framework Decision, its complement by non-legislative measures concerning assistance to victims, monitoring, prevention in countries of destination and origin, training and police cooperation.

Therefore, with the above statements of the Commission, the political will to address an integrated and victim-centric approach in the trafficking of human beings also became a reality in the European Union. Starting from the option that consists of adopting a new Framework Decision that substitutes FD 2002/629/JHA, the Council proposed to the Commission that it makes a proposed Framework Decision, the previously mentioned Council Framework Decision on preventing and combating trafficking in human beings and protecting victims ${ }^{38}$, which involved the adoption of an integrated and comprehensive approach to combat this reality. It not only adopted the broad definition of the crime of human trafficking included in United Nations instruments and the Council of Europe Convention, but also included the trafficking of human beings for the purpose of organ removal.

The approval of the Treaty on the Functioning of the EU or the Treaty of Lisbon of 2009, with the subsequent disappearance of its structure of pillars, led to the expiration of this initiative. This led to its formal withdrawal and replacement by the proposed Directive of the European Parliament and the Council on preventing and combating trafficking in human beings, and protecting victims, repealing Framework Decision 2002/629/JHA of 29 March $2010^{39}$.

This new proposal would be handled in accordance with the Treaty of Lisbon, which has led to the subsequent adoption of Directive 2011/36/EU. One might think that since it is simply adapting the process for the processing of the former standard to the co-decision procedure, with the initiative being from the same European body, the contents of both provisions is coincidental. However, even though there are clear similarities between the two texts, their content is not equivalent. While both initiatives are singled out, in relation to Framework Decision 2002/629/JHA, generally with in-depth issues such as crime prevention or protection and assistance to victims as well as the criminalization of criminal behaviour, the proposed Directive of 2010 is broader than the proposed Framework Decision of 2009, especially in aspects such as assistance and support to the victims.

Based on the text of the Directive proposal, adopted by the Commission on 29th March, 2010, and submitted both to the Parliament and the Council on the same date, the Committee on Civil Liberties, Justice and Home Affairs and the Committee on Women's Rights and Gender Equality of the Parliament set out a number of changes to the Parliament's draft report ${ }^{40}$ that were then largely assumed by the Parliament and which were included in the originally proposed text, although it did not lead to a substantial modification of its structure nor its contents. Finally, the

\footnotetext{
${ }^{38}$ COM (2009) 136 final.

${ }^{39}$ COM (2010) 95 final.

${ }^{40}$ See European Parliament, Draft Report on the proposal for a directive of the European Parliament and the Council on preventing and combating trafficking in human beings, and protecting victims, repealing Framework Decision 2002/629/JHA, 28. 6. 2010, pdf. file available at http://ec.europa.eu/prelex/ (14-02-2012).
} 
European Parliament adopted the legislative resolution of the Directive proposal ${ }^{41}$, amending it in some respects. Once the Commission expressed its commitment on the amendments made at the first reading by the Parliament, and once the Council came to a consensus, the project was approved on 21 March 2011, with the text of the Directive being definitively signed, both by the President of the European Parliament and the Council on 5th April, 2011. The entry into force of that document, whereby, as was said, brings forth the final change of direction of the Union's policy on the trafficking of human beings towards victim-centrism, occurred on 15th April, 2011, coinciding with the date of its publication in the Official Journal of the European Union ${ }^{42}$. This rule states that those comprising the Union who have participated in its approval must observe this law in a horizon that ends on 6th April, 2013. All member States of the Union, and finally the United Kingdom as well ${ }^{43}$, with the exception of Denmark, are subject to the Directive, which will replace Framework Decision 2002/629/JHA.

\section{Directive 2011/36/EU: Structure and Content}

Directive 2011/36 EU of the European Parliament and the Council on preventing and combating trafficking in human beings and protecting its victims adopts a holistic approach in addressing this phenomenon. In this sense, among the standard's recitals, it is expressed that this phenomenon constitutes a grave violation of human rights whose avoidance and combating has become a priority for the Union and the Member States. Based on this observation, the preamble identifies the approach of the Directive as global and comprehensive as well as based on human rights. This holistic treatment early on in the preamble leads the Directive to identify the adoption of an approach that is built on the 3P policy that had already been adopted in the Palermo Protocol, focusing not only on the prosecution of traffickers but also in prevention and victim protection. In addition to these areas of applicability in the Directive, there is a fourth area of influence, so much clearer in the final text of the Directive than in its proposal, focused on cooperation. In this regard, the recitals of the Directive make reference to both the need for cooperation between law enforcement of different countries to strengthen the fight against human trafficking, regarding the need to foster collaboration between States and the organizations of civil society ${ }^{44}$, and finally, in relation to the need to promote coordination among international organizations with competences in relation to action against trafficking

\footnotetext{
${ }^{41}$ See European Parliament legislative resolution of 14th December, 2010 on the proposal the Directive and Position of the European Parliament adopted at first reading on 14th December, 2010, both available at www. europarl.europa.eu.

${ }^{42}$ See supra fn 1.

${ }^{43}$ Originally, this Directive was not applicable to the UK. However, after its entry into force, the British government expressed its willingness to adopt it. See, Cowen, "Victims of human trafficking: protection from punishment", Archbold Review, 7, 2011, p. 5. Finally, the Commission, by its Decision of 14th October, 2011, declared the applicability of Directive2011/36/UE both to UK and Northern Ireland.

44 These ideas are reflected in recitals 5 and 6 Directive's preamble, not contained in the proposal.
} 
in human beings, in order to avoid the duplication of work. Despite the adoption of this approach, the Directive provides specific protection measures for victims of human trafficking without addressing the conditions of the residence of victims in the territory of the Member States ${ }^{45}$. Regarding the residence conditions of victims in trafficking in the territory of the Union, what is provided for in the provisions of Council Directive 2004/81/EC of 29 April 2004 must be applied. The above rule does not meet the standards of protection for victims of trafficking who are assumed to be in victim-centric positions, since the absolute orientation of the reflection period to promote collaboration with the administration of justice can lead to situations of victim vulnerability, as well as the limitation in granting subsequent special residence permits for cases where the victim cooperates with the administration of justice.

Moving on to the analysis of the content of this Directive, we can point out that its structure recalls, in many respects, the Warsaw Convention, mainly in the fact of adopting a global approach. However, Directive 2011/36/EU adopts a different order in regulation, since it gives greater prominence to the provisions adopted as regards prosecution, which ranks first ${ }^{46}$, deferring to a later time the establishment of measures for assistance, support and protection to victims as well as those relating to the prevention and the cooperation and coordination in the fight against this phenomenon. Prosecution constitutes the main objective pursued by the Directive, despite references to the adoption of a holistic approach. This is already apparent from Article 1, which determines the aim of the rule, where its slope leans towards being punitive, leaving the rest in second place ${ }^{47}$.

Despite the importance given by this rule to the aspects that have to do with the prosecution of traffickers, given that the prevention of this type of conduct as well as the protection of victims constitute aspects that are closer to an approach to trafficking through the prism of human rights, the statement of the Directive's contents will be initiated by means of these aspects. It should be noted that even if it means subverting the order of the articles, both the prevention of trafficking as well as the protection of its victims are issues that often need to be addressed regardless of the eventual implementation of criminal proceedings to prosecute the commission of the offence, thus it is also from a logical point of view that its first approach is justifiable.

\footnotetext{
${ }^{45}$ As expressed in recital 17 preamble.

${ }^{46}$ In the Warsaw Convention, requirements regarding the prosecution of the crime of trafficking are referred to in Chapter IV of the Convention, after dealing with issues such as purposes and scope of the Convention (Chapter I), the prevention of this crime (Chapter II), and measures of protection of victims (Chapter III). Widely about the content of the convention, see Villacampa Estiarte (fn 4) p. 176 et seq.

${ }^{47}$ According to art. 1 Directive 2011/36/EU "This Directive establishes minimum rules concerning the definition of criminal offences and sanctions in the area of trafficking in human beings. It also introduces common provisions, taking into account the gender perspective, to strengthen the prevention of this crime and the protection of the victims thereof".
} 


\section{Measures to prevent the trafficking of human beings referred to in Directive 2011/36/EU}

The preventive measures are more succinctly provided for than in the Warsaw Convention. A single provision is dedicated to these measures, Art. 18. Under that article, it stipulates both the adoption by Member States for measures aimed at deterring and reducing demand through education and training, and the adoption of appropriate measures, such as information and awareness, as well as education and research campaigns, which can be adopted in cooperation with civil society organizations, aimed at reducing the risk that people, especially children, become victims of trafficking in human beings. It also provides for the States to promote regular training for officials who are likely to come into contact with real victims and potential victims so they can identify and treat such victims. The class of officers to whom this demand for specific training is addressed to, included in Art. 18.3 of the Directive, specifically mentions police officers as the first line, as numbered in the recitals of the Directive's preamble -recital 25 -. Included among them, besides police officers, are border guards, immigration officials, prosecutors, lawyers, members of the judiciary and court officials, labour inspectors, the staff responsible for social, child, and health affairs, as well as the consular staff, even when the action is directed at other groups of public officials who may come into contact with victims of human trafficking in the performance of their duties.

In relation to demand, that the Directive identifies with the factor that fosters all forms of exploitation related to trafficking in human beings, Art. 18.4 stipulates that Member States may consider adopting measures to criminalize the use of the services of people who are knowingly being exploited. However, this command is not established as mandatory, as in Art. 19 of the Warsaw Convention ${ }^{48}$.

\section{Assistance and protection for victims of trafficking in Directive 2011/36/EU}

With regard to actions to ensure protection and assistance to victims, the Directive is more comprehensive in its regulation. This was already the case in its first version, corresponding to the Directive proposal, but it is even more so having now been processed. Throughout it, specific provisions have been added to the first version of the document that protect both victims in general -regardless of that which characterizes criminal proceedings- and especially unaccompanied minors, concerning their assistance, support and protection ${ }^{49}$, and finally the possibility of public compensation recognized to victims of such behaviour ${ }^{50}$.

\footnotetext{
${ }^{48}$ Art. 18.4 Directive 2011/36/EU specifically provides that "In order to make the preventing and combating of trafficking in human beings more effective by discouraging demand, Member States shall consider taking measures to establish as a criminal offence the use of services which are the objects of exploitation as referred to in Article 2, with the knowledge that the person is a victim of an offence referred to in Article 2".

${ }^{49}$ The Directive proposal did not contain specific provisions for this particular type of victims. However, during the processing of the Directive 2011/36/UE a specific provision was included, Art. 16, entitled "assistance, support and protection for unaccompanied child victims of trafficking in human beings".
} 
As for the measures referred to in Directive 2011/36/EU whose main aim consists in protecting and assisting victims, these measures are much more profuse than those aimed at crime prevention. Already in the Directive's preamble, it has become quite clear that victim protection and assistance is given much more attention than prevention. Almost all of recitals 17 to 24 of the preamble are dedicated to this issue. These recitals make clear that, after recalling that the Directive does not address the conditions of residence for victims of trafficking in the territory of the Member States, these victims need to be able to exercise their rights effectively. Hence, they should be provided assistance and support before the start of criminal proceedings, throughout its course and during a sufficient period of time after it has finished. The duty therefore emerges for States to provide resources to enable the assistance, support and protection for victims. This duty arises whenever there are reasonable indications that a person has been a victim of trafficking in human beings, regardless of their willingness to act as a witness, with such assistance being given unconditionally at least during the period of reflection when the victim does not reside legally in the State. This duty for providing assistance fails when, once the identification process has concluded or the period of reflection has expired, it is considered that the victim in question is not eligible to obtain a residence permit or does not have legal resident status in the territory of the Member State or if the victim has left the territory of that Member State, or the State in question is not obliged to continue providing assistance or support under this Directive. It is assumed that assistance and support for victims should be offered with their consent, so that a victim's refusal to accept such measures must be respected.

Regarding protective measures to be taken concerning victims under criminal proceedings, the preamble of the Directive recalls how the provisions of Framework Decision 2001/220/JHA of the Council of 15 March 2001 will be applied to the victims of human trafficking, on the standing of victims in criminal proceedings, indicating that their right to protection and compensation is recognised, also ensuring that they have legal advice made available to them and, if appropriate, legal representation, thus avoiding secondary victimization.

Particular attention is given in the preamble of the Directive 2011/36/EU to child victims of trafficking in human beings, who are considered particularly vulnerable victims, with the resulting need for the provision of additional security measures, especially in the case of unaccompanied minors ${ }^{51}$.

In keeping with these considerations, the body of the Directive provides measures regarding assistance and support for victims in general as well as protective measures to be taken under specific criminal procedures. Together with what must be adopted in relation to any victim of trafficking in human beings, measures regarding

\footnotetext{
${ }^{50}$ Neither in this aspect did the proposal contain any specific provision. However, it was introduced over the processing as a Directive, having been established in Art. 17.

${ }^{51}$ In relation to this particular case, one that was not specifically addressed in the Directive proposal, two new recitals have been added to the preamble in the Directive 2011/36/UE, numbers 23 and 24.
} 
child victims stand out, especially those to be imposed in relation to unaccompanied minors.

\section{a) Measures to assist and protect victims of trafficking in human beings in general}

Starting with general assistance and support measures, Art. 11 of the Directive provides that States must take measures to ensure support for victims before, during and after criminal proceedings, so that they can exercise the rights provided for in Framework Decision 2001/220/JHA of 15 March 2001, on the standing of victims in criminal proceedings ${ }^{52}$ and in this Directive 2011/36/EU. The precept clarifies that once the competent authorities have reasonable-grounds indication for believing that the person might have been subjected to any of the offences listed in Art. 2 and 3 of the Directive, Member States shall take the necessary measures to ensure that a person is provided with assistance and support, in a manner that its provision is not subject to the will of the victim that cooperates in the criminal investigations, or the trial, while remembering to respect the limitations set out in Directive 2004/ $81 / \mathrm{EC}$ or similar standards ${ }^{53}$. In order that the assistance to be provided is done so as soon as possible, it is ruled that States shall take the necessary measures to establish appropriate mechanisms aimed at the early identification, care and support for victims, in cooperation with the relevant support organizations.

The content of the measures of assistance and support is determined in Art. 11 of the Directive, provided in Section 5, which will include at least a standard of living capable of ensuring the victims' subsistence through measures such as the provision of appropriate and safe accommodation and material assistance, medical treatment, including psychological assistance, counselling and information as well as interpretation and translation services when appropriate.

The provision of said care and support to the victim, as has already been indicated exposes the preamble of the Directive 2011/36/EU, requires his/her consent and knowledge of the facts, which means they must be agreed by the victim ${ }^{54}$. Art. 11.6 of the Directive states the extremes of informing the victim in order to decide whether the victim wants to be given the assistance.

To conclude the list of measures for general assistance and support applicable to all victims, the right to compensation from public funds is acknowledged ${ }^{55}$.

\footnotetext{
52 That can be structured as a right to information, assistance, protection, participation in the proceedings and compensation/ repair. A detailed explanation of the content of each one of these rights can be found at Baca/ Echeburúra/Tamarit (coords.), Manual de Victimología, Ed. Tirant lo Blanch, Valencia, 2006, p. 324 et seq.

53 The mentioned reference to Directive 2004/81/EC as a sign of a possible limit to provide unconditional assistance to those whom do not cooperate with the justice system was introduced in the processing of the Directive in the last paragraph of Art.11.3, which did not appear in the text of the proposal.

${ }^{54}$ However, it can be inferred from the text of the Directive that the voluntary receipt of assistance is not predicated of victims with special needs. In relation to such individuals, Art.11.7 Directive establishes "Member States shall attend to victims with special needs, where those needs derive, in particular, from whether they are pregnant, their health, a disability, a mental or psychological disorder they have, or a serious form of psychological, physical or sexual violence they have suffered".

${ }^{55}$ See Art. 17Directive.
} 
Regarding child victims, the terms in which special protection and assistance to such victims must be provided are singled out in Arts. 13 to 15 of the Directive, both in general and in the context of criminal proceedings. As the principal informers on the provision for this type of assistance and support, Art. 13 of the Directive provides that in the case of child victims, the best interests of the child shall be a primary consideration. It also indicates that in cases where the age of the victim of trafficking in human beings is uncertain and there is reason to believe that the person is a child, the victim shall be considered as such for the purposes of assistance support and protection.

As for the assistance and support generally referable to child victims, the goal is that it has a more lasting nature, that is, the approach of a strategy for assistance and support is proposed, not only in the short term, but with a view to its continuation. Hence, it is necessary that specific measures for the physical and psychosocial recuperation of the minor be undertaken after an individual assessment of the specific circumstances of such victims, taking into account their views, needs and interests. In the case of minors, in addition to the measures of support and assistance for any victim of trafficking under Art. 11 of the Directive, Member States should facilitate access to education, although in accordance with national law. In the case of this type of victim, it is also established that as far as possible, Member States adopt measures to provide assistance and support to families of the victims, when in the territory of a Member State, informing them, wherever possible and appropriate, in the terms established in Art. 4 of FD 2001/220/JHA.

Finally, also in the case of child victims, ex novo is provided for in the text of the Directive the possibility of appointing a guardian or a representative for the child victim from the moment the child is identified as such when, in accordance with national law, a conflict of interest with the minor prevent the holders of parental responsibility to defend the interests of the child or represent the child. For instance, think about those cases where the child's own parents are the prosecuted, or already accused for the crime itself of human trafficking, which has led to the victimization of the minor.

As already mentioned, Directive 2011/36/EU is particularly sensitive to the case of unaccompanied minors, more than the proposal of Directive, which did not contain any specific provision in this regard. It was within the European Parliament that the inclusion of specific provisions was proposed concerning the assistance, support and protection of unaccompanied minors, which explains the inclusion of Art. 16 of the Directive. This provision states that the assistance and support measures applicable to all minors under the provisions of Art. 14 of the Directive take into account the particular situation of unaccompanied minors who are victims of trafficking in human beings, anticipating the adoption of necessary measures for the delineation of a lasting solution based on an individual assessment of the interests of the child, without indicating what it can be $\mathrm{e}^{56}$, as well as adopting measures that are relevant so that, where appropriate, a guardian is appointed for each unaccompanied minor who is a victim of trafficking. 


\section{b) Measures to protect victims of human trafficking under the criminal proceedings}

The measures specifically aimed at protecting victims of the offence of trafficking in human beings in criminal investigations and proceedings are referred to in Art. 12 of the Directive. The guiding principle which forms the basis for the provision of such protective measures, judging by the provisions of recital 20 of the Directive's preamble, is precisely to avoid secondary victimization, as well as the production of further trauma during the criminal proceedings. To this end, it should kept in mind that the victims of such crimes are granted the same rights contained in Framework Decision 2001/220/JHA, on the standing of victims in criminal proceedings, for any victim of crime, in addition to those outlined in the Directive that is currently being addressed. This Directive provides that victims of trafficking have immediate access to legal counselling and legal representation, including for purposes of claiming compensation, although the right to counsel recognized in the terms are made in accordance with the standing of the victim in the legislation of the country concerned. The cost-free status of both prerogatives is not guaranteed, except in cases where the victim does not have sufficient financial resources.

Directive 2011/36/EU starts from the need that victims of the crime of human trafficking receive treatment that is tailored to their individual needs during investigations and prosecutions. Hence, in the body -Art. 12.3- the Directive specifies that Member States must ensure that victims of this crime receive appropriate protection based on individual risk assessment, which can lead to being given access to witness protection programmes or similar measures.

In any case, that is, regardless of the situation of more or less individual risk accredited by the aforementioned individual assessment, the Directive insists in its articles on the need to avoid secondary victimization. To serve this purpose, it is expected that States' Parties ensure that victims of this crime receive specific treatment aimed at preventing this type of victimization, even without prejudicing the rights of a defence ${ }^{57}$. The efforts of the Directive are oriented towards the direction of avoiding the unnecessary repetition of interviews as well as the visual confrontation between the victim-witness and the charged-accused. In this sense, Art. 12.4 of the Directive provides that, as far as possible, practices like the unnecessary repetition of interviews, visual contact between victims and defendants during the giving of evidence ${ }^{58}$, giving of evidence in an open court or unnecessary questioning concerning the victim's private life must be avoided by the courts.

\footnotetext{
${ }^{56}$ Although recital 23 in the preamble states that constitute possible durable solutions return and reintegration into the country of origin or the country of return, integration into the host society, granting of international protection status or granting of other status in accordance with national law of the Member States.

${ }^{57}$ Perhaps because of the possible infringement of defense rights of the accused/ defendant that it could represent, in the text of the Directive has been removed the possibility,-admitted in Art.11.3 of the proposal- that States could allow, when and if it proceed in accordance with the basic principles of its legal system, that the identity of victims of trafficking in human beings taking part in the proceeding as a witness was not revealed, testifying as anonymous witnesses.

${ }^{58}$ In this regard, recital 20 in the preamble suggests that the practice of oral evidence can be anticipated considering the following passage "Unnecessary repetition of interviews during investigation, prosecution and trial should be
} 
In the case of child victims, the Directive abounds in the need to avoid secondary victimization. In this sense, Art. 15 of the Directive features in detail how to carry out examinations of child victims. Along with the ability to anticipate or preestablish the taking of evidence in general terms ${ }^{59}$, it provides that in criminal proceedings for offences of trafficking in human beings the examinations must take place without undue delay following the disclosure of the facts to the competent authorities, which take place in assigned places or adapted for that purpose, which are directed -if necessary - by or through professionals trained for this purpose, that the same people conduct all the examinations of the child, that the number of examinations be as small as possible and be utilized only when strictly necessary for the purposes of criminal investigations and prosecutions and, finally, that the minor is accompanied by his/her representative or, where appropriate, an adult chosen by the minor, unless a sound decision has excluded that person. Even in cases where the taking of evidence is not pre-established and anticipated, and even those in which it is, Art. 15.5 of the Directive provides that the hearing take place without the presence of the public and that the child victim may be heard without being present in the courtroom, through the use of appropriate communication technologies.

In short, it appears from the precept's tone that it is intended to enable the practice of oral evidence to be as least harmful as possible, seeking execution mechanisms adapted to the special characteristics of these victims, thus guaranteeing their privacy and the avoidance of visual confrontation with the accused/defendant, to the point of promoting the widespread practice of early or pre-constituted testimony.

In the case of minors, immediate access to free legal advice and free legal representation is also guaranteed, although there is an exception to the access to these rights, as in the case of adults, when the minor has financial resources at their disposal $^{60}$. Finally, the child victim of the crime of trafficking in human beings is recognized, according to the standing of the victims in the relevant legislation, the right to be appointed a representative in investigations and criminal proceedings, for cases of an unaccompanied minor in the event that the domestic law removes the child's representation to the holders of parental responsibility because of a conflict of interest between them and the minor -Art. 15.1 Directive- and in any event in cases of unaccompanied minor victims or those who have been separated from their families -Art. 16.4 Directive.

\footnotetext{
avoided, for instance, where appropriate, through the production, as soon as possible in the proceedings, of video recordings of those interviews".

${ }^{59}$ Art 15.4 disposes that "Member States shall take the necessary measures to ensure that in criminal investigations of any of the offences referred to in Articles 2 and 3, all interviews with a child victim or, where appropriate, with a child witness, may be video recorded and that such video recorded interviews may be used as evidence in criminal court proceedings, in accordance with the rules under their national law".

${ }^{60}$ In contrast to what happened in the Directive proposal, where the gratuity of such services did not provide for exceptions in the case of child victims.
} 


\section{Provisions to prosecute the crime of trafficking in human beings in Directive 2011/36/EU}

Thirdly, according to the exposition order taken, though first in the order of the provisions of the Directive, it intends to put the establishment of rules leading to the harmonization of national laws regarding the prosecution of trafficking offences on the right path. Thus, with regards to the rule that currently concerns us, in the approach of laws initiated by FD 2002/629/JHA, it has an impact in both looking for a harmonization of substantive criminal law provisions as it does on some issues of criminal procedure.

The harmonization of national laws of the countries that comprise the Union continues to be the main objective of this rule. True, the number of correcting provisions both in the protection and assistance of victims of this crime as well as others oriented towards cooperation have increased; despite this, the provisions for criminal harmonization remain the most numerous, since Arts. 2 to 10 of the Directive are dedicated to these.

\section{a) Provisions to pursue the harmonization of substantive criminal law}

Starting with the rules of substantive criminal law, Art. 2 of the Directive raises the need to criminalize the offence of trafficking in human beings, defined in terms similar to the replaced Framework Decision 2002/629/JHA, while clarifying that this behaviour must be incriminated when committed intentionally and specifically including new ways of exploiting that are not covered by $i^{61}$, such as those aimed at forced begging, consistently carrying out criminal activities or crimes that take steps towards the removal of organs ${ }^{62}$.

In addition to the anticipated incrimination of conduct in cases of trafficking accomplished in terms of authorship, as customary, we find in Art. 3 of the Directive that States should adopt measures to criminalize inciting, aiding, abetting and attempting.

As for penalties for the offences listed in Art.2, the preamble reasons that the States increasing concern about this growing phenomenon justifies a much harder approach regarding sanctions in addition to the harmonization of these sanctions. While the current Directive 2011/36/EU does not meet the punitive requirements of the proposed Framework Decision of 2009, it far exceeds the minimum sentence requirements that are in force until now. On the one hand, FD 2002/629/JHA required the imposition of effective, proportionate and dissuasive criminal penalties, which may entail extradition for the basic type of the offence, as long as the maximum should not be inferior to eight years of imprisonment for qualified

\footnotetext{
${ }^{60}$ See Art. 2.1 Directive.

${ }^{61}$ This point is clarified in the preamble of the Directive, recital 11, which adds to new forms of exploitation referred to in the text, the cases of trafficking for the purpose of illegal adoptions or forced marriages. Art. 2.3 Directive indicates that "exploitation shall include, as a minimum, the exploitation of the prostitution of others or other forms of sexual exploitation, forced labour or services, including begging, slavery or practices similar to slavery, servitude, or the exploitation of criminal activities, or the removal of organs".
} 
types $^{63}$. On the other hand, Art. 23.1 of the Warsaw Convention, which links the countries comprising the Council of Europe that ratified it, provided the necessary imposition of prison sentences for this type of conduct that could give rise to extradition.

Punitive requirements from the Union for this type of crime have increased substantially with the new Directive 2011/36/EU. By virtue of Art. 4.1, the maximum term of imprisonment for the crime of trafficking as defined in Art. 2 of the Directive must be at least five years. This minimum reaches the maximum penalty of at least ten years in prison -Art. 4.2 of the Directive- in cases where the offence is committed against particularly vulnerable victims -always including children ${ }^{64}$ committed in the context of a criminal organization ${ }^{65}$, has led to the deliberate endangerment or by gross negligence of the life of the victim, or has been committed using serious violence ${ }^{66}$ or causing particularly serious harm to the victim. The fact that the offence is committed by a public official in the performance of their duties appears to be configured as an aggravating circumstance that, unlike those established in no. 2 of Art. 4 , does not have a minimum for a maximum penalty to be added to the basic type ${ }^{67}$.

Along with the criminal responsibility of individuals, as is customary in community provisions in this regard, the criminal responsibility of legal persons is set forth in articles, having committed the offence on account of them, whether for those who hold a leading position in the context of the legal person, either by those who without displaying it may have committed the crime due to lack of supervision or control by one of these people, if the offence is committed for the benefit of the legal person. In short, the basis for criminal liability of legal persons is maintained regarding what is already established by the FD 2002/629/JHA, without seeing large discrepancies in the penalties to be imposed, except for the name given to the penalty in some cases.

As for the sanctions imposed on the crime of trafficking - be it performed, attempted, as an author or as an accomplice- the greatest addition in the final text of the Directive in relation to the proposed Directive is the specific provision for seizure and confiscation of the instruments and proceeds in all the conduct related

\footnotetext{
${ }^{62}$ See art. 3 FD 2002/629/JHA.

${ }^{63}$ According to recital 12 of the preamble, other factors that can be taken into account when assessing the vulnerability of a victim include, for example, gender, pregnancy, state of health and disability.

${ }^{64}$ According to the text of the Directive a criminal organization must be understood within the meaning of Council Framework Decision 2008/841/JHA of 24 October 2008 on the fight against organised crime. Art. 1.1 of this rule considers that a criminal organization means "a structured association, established over a period of time, of more than two persons acting in concert with a view to committing offences which are punishable by deprivation of liberty or a detention order of a maximum of at least four years or a more serious penalty, to obtain, directly or indirectly, a financial or other material benefit".

${ }^{65}$ Recital 12 of the preamble includes cases involving serious violence such as torture, forced drug/medication usage, rape or other serious forms of psychological, physical or sexual violence.

${ }^{66}$ This interpretation is sustained, although the text of the Directive can be confusing in this aspect, because the aggravating circumstance for public officials is regulated separately, not among those of Art.4.2, to which correspond a minimum of maximum penalty, often years of imprisonment, but in Art.4.3. This last paragraph establishes "member States shall take the necessary measures to ensure that the fact that an offence referred to in Article 2 was committed by public officials in the performance of their duties is regarded as an aggravating circumstance".
} 
to human trafficking that the Directive provides for. The reason that lies at the base of this inclusion, while taking advantage of regulating instruments in this particular subject at an international and European level, is motivated by the goal of encouraging the use of instruments and products stemming from seized and forfeited offences to support assistance and protection for victims.

The last of the provisions of the Directive that focuses on the harmonization of substantive criminal law provisions is undoubtedly the greatest of what is new. In similar terms to what was already established by Art. 26 of the Warsaw Convention, albeit more extensively, it offers the possibility of non-prosecution or sentencing of the victim in Art.8 of the regulatory text. The Union's provision is broader than the Warsaw Convention because it not only provides the possibility of stipulating a personal cause for the waiver of the penalty, but even provides for the possibility that the victim is not even tried. We find ourselves, therefore, not only before a measure of a substantive nature, but one that may involve a procedural nature as well. However, on the other hand, with acknowledgement to an operation area wider than the homologous precautionary measures of the Warsaw Convention, they are confined to greater detail in Directive 2011/36/EU, the cases that can be applied, since it is a requirement that the victim has been "compelled to commit" the criminal acts "as a direct consequence of being subjected to any of the acts referred to in Article 2."

\section{b) Provisions directed at the harmonization of some procedural issues}

With regards to the measures relating to criminal procedure under Directive 2011/36/EU, basically, it takes steps to dwell on the consideration of crimes of trafficking as actionable offences and to extend the statute of limitations in cases where the victim of a crime of trafficking is a minor, and ensure the proper training and adequate resourcing of research for active professionals in this field -Art. 9.

Finally, along with those already mentioned, as FD 2002/629/JHA already did, provisions are provided for that lead to an extension of the jurisdiction of the courts of the Member States which extends beyond their territory to judge these crimes. In this regard, Art. 10 provides that Member States shall take the necessary measures to establish its jurisdiction over the offences referred to in the Directive where the offence is committed in whole or in part within its territory, or if the offender is one of their nationals. In those cases where the offence is committed against one of the nationals of the Member State or against a person who habitually resides in its territory, or when the offence is committed for the benefit of a legal person established in its territory or its author habitually resides in its territory, the extension of jurisdiction is optional, not mandatory as in the first set of assumptions. In the provisions so far, Art. 10 of Directive 2011/36/EU shares an important part of the content of Art.31 of the Warsaw Convention, while also including in the passive personality principle victims with legal residence in the territory of the State and extending the competence to acts committed in favour of a legal person established in its territory. However, what is substantially different about both 
provisions lies in the rest of the contents of the corresponding article, as if in Art. 31.3 of the Warsaw Convention a kind of positivization of the principle of supplementary justice is provided, No. 3 of Art. 10 of the Directive stipulates that in cases where the offender is a national of a Member State, it will adopt the necessary measures to ensure that its jurisdiction is not subject to the condition that the act constitutes a criminal offence in the place where it was held or that the proceedings can only be initiated after the filing of a deposition by the victim in the location where the infringement occurred, or a condemnation of the State in whose territory the infringement occurred ${ }^{68}$. In short, the Directive 2011/36/EU aims to ensure the extraterritorial jurisdiction of the Member States on the basis of the principle of active personality.

\section{Measures towards cooperation and monitoring the implementation of the Directive}

To conclude this explanation of the contents of Directive 2011/36/EU, we must point out that as opposed to what happened with the proposal of the Directive which hardly stipulated provisions to this effect, it includes rules aimed at strengthening cooperation between the States and civil society actors in order to strengthen the fight against this criminal phenomenon. Therefore, we can confirm that, as already mentioned, the policy followed by the Union with the adoption of this Directive, rather than $3 \mathrm{P}$ policy, can be characterized as $4 \mathrm{P}$ policy, which covers the flank of coordination in addition to the prevention, protection and prosecution of the crime. This is considered in several recitals in the preamble to the Directive ${ }^{69}$.

Despite the importance that its preamble gives to the coordination between different actors involved in fighting trafficking in human beings, little content related to this fourth aspect of a comprehensive approach can be found reflected in the articles of the provision. However, a new rule was included during the processing of the Directive, Art. 20, that under the rubric of "coordination of the Union strategy against trafficking in human beings, states that "Member States should facilitate the task of an EU Coordinator for combating trafficking in human beings $^{70}$, to whom statistical information should be given by the States, and which requires the prevision of a national rapporteur or an equivalent mechanism in each State.

\footnotetext{
${ }^{66}$ The adoption of such measures is not mandatory, but optional, in the cases referred to in No.2 of art.10 Directive. That is, those in which the victim is one of the nationals or a person who is a habitual resident in the territory of the State, the offence is committed for the benefit of a legal person established in its territory, or the offender is a habitual resident in its territory.

${ }^{67}$ Especially in recitals No. 5 -referred to cooperation among States- 6 - referred to the cooperation with civil society organizations-, 27 - regarding the implementation of national monitoring systems and national rapporteurs-, 28- development of data collection methods to produce comparable statistics- and 29 - in relation to the appointment of an anti-trafficking coordinator at the Union level-.

${ }^{68}$ A position held by Myria Vassiliadou since being appointed on 14th December, 2010, by the Commission.
} 


\section{Conclusions}

Comparing the analysed contents of Directive 2011/36/EU with those that any regulation should contain if designed for a victim-centric policy on trafficking in human beings, in accordance with the opinion expressed by the EU Experts Group on trafficking in human beings in its 2004 report, we can conclude that the adoption of this Directive represents in effect a radical change in policy that hitherto the EU had been observing in this regard. However, although it seems to have definitively abandoned a crime-centric approach with this new standard, as has already been mentioned, the provisions of this new rule concerning the criminalization of behaviours, that is, those that cover the flank of political prosecution in a polyhedral policy, are the most numerous. Added to this, the criminalization of behaviour seems to be the fundamental objective of the Union through the adoption of the 2011 Directive, judging by the provisions of the rule that indicate its objective. Nevertheless, it is undeniable that the references of the new Directive, primarily to the protection of victims of human trafficking, are clearly closer to the profile of provisions that focus on a holistic or victim-centric approach. Nonetheless, despite the profuse of articles on this subject, the rule does not fully begin to safeguard the position of victims in human trafficking, precisely because it has no effect regarding the residence permit or the conditions in which victims of human trafficking can achieve legal residency in the country of destination. Both issues will continue to be regulated by Directive 2004/81/EC, which as previously indicated, is limited in granting a residence permit, subject to the cooperation of the victim of trafficking with the justice administration.

This limitation still remaining in the recognition of a legal residence status to victims of trafficking conditioned on their willingness to collaborate in hypothetical criminal proceedings against the trafficker enables us to see that, behind the alleged assumption of the victim-centric paradigm by means of the Directive, lies the policy of a fortress Europe. The Europe that denies citizenship status to immigrants even if they were victims of trafficking is also expressed by this standard, although hidden behind the pristine screen of a victim-centric approach to this phenomenon. Hence, it can be concluded that although the adoption of Directive 2011/36/EU constitutes a definite step of the Union in the pursuit of the adoption of an approach to this reality from the perspective of protecting human rights, the conclusion to this process is still lacking. This should be done by regulating the conditions of victims staying in the territory of the countries of destination due to humanitarian reasons, rather than the will of the victims to collaborate with the administration of justice to prosecute those responsible. 
